\title{
Études/Inuit/Studies
}

\section{Jørgen Meldgaard's film works and books on art from the}

\section{Arctic}

\section{Les films de Jørgen Meldgaard et ses livres sur l'art de l'Arctique}

\section{Anne Mette Jørgensen}

Volume 37, numéro 1, 2013

URI : https://id.erudit.org/iderudit/1025258ar

DOI : https://doi.org/10.7202/1025258ar

Aller au sommaire du numéro

Éditeur(s)

Association Inuksiutiit Katimajiit Inc.

Centre interuniversitaire d'études et de recherches autochtones (CIÉRA)

ISSN

0701-1008 (imprimé)

1708-5268 (numérique)

Découvrir la revue

Citer ce document

Jørgensen, A. M. (2013). Jørgen Meldgaard's film works and books on art from the Arctic. Études/Inuit/Studies, 37(1), 127-145.

https://doi.org/10.7202/1025258ar
Résumé de l'article

L’archéologue danois Jørgen Meldgaard (1927-2007) était un cinéaste passionné. Les archéologues d'aujourd'hui pourraient s'inspirer de sa passion pour ce médium qu'est le film. Il a produit trois documentaires incontournables au cours de sa carrière, chacun d'eux illustrant une tendance importante de la représentation scientifique de l'Autre durant la seconde partie du $\mathrm{XX}^{\mathrm{e}}$ siècle. Cet article analyse ses films en portant une attention particulière à la manière dont Meldgaard est passé d’une représentation des Inuit en tant qu'objets à une représentation en tant que sujets. Il effectue également une comparaison de ses films avec ses deux ouvrages sur l'art inuit et les replace dans le contexte des développements méthodologiques contemporains en archéologie et en anthropologie. Il conclut en recommandant aux futurs archéologues de suivre l'exemple de Meldgaard en s'engageant dans le partage de la connaissance, par l'intermédiaire des médias audiovisuels, avec les gens concernés par les fouilles archéologiques, plutôt que de laisser entièrement la représentation de la connaissance archéologique aux professionnels des médias. 


\title{
Jørgen Meldgaard's film works and books on art from the Arctic
}

\author{
Anne Mette Jørgensen*
}

Résumé: Les films de Jørgen Meldgaard et ses livres sur l'art de l'Arctique

L'archéologue danois Jørgen Meldgaard (1927-2007) était un cinéaste passionné. Les archéologues d'aujourd'hui pourraient s'inspirer de sa passion pour ce médium qu'est le film. Il a produit trois documentaires incontournables au cours de sa carrière, chacun d'eux illustrant une tendance importante de la représentation scientifique de l'Autre durant la seconde partie du XX $\mathrm{X}^{\mathrm{e}}$ siècle. Cet article analyse ses films en portant une attention particulière à la manière dont Meldgaard est passé d'une représentation des Inuit en tant qu'objets à une représentation en tant que sujets. Il effectue également une comparaison de ses films avec ses deux ouvrages sur l'art inuit et les replace dans le contexte des développements méthodologiques contemporains en archéologie et en anthropologie. Il conclut en recommandant aux futurs archéologues de suivre l'exemple de Meldgaard en s'engageant dans le partage de la connaissance, par l'intermédiaire des médias audiovisuels, avec les gens concernés par les fouilles archéologiques, plutôt que de laisser entièrement la représentation de la connaissance archéologique aux professionnels des médias.

\begin{abstract}
Jørgen Meldgaard's film works and books on art from the Arctic
Danish archaeologist Jørgen Meldgaard (1927-2007) was a dedicated filmmaker, and today's archaeologists may find inspiration in his engagements with the medium of film. He produced three major pieces of film work during his career. Filmed in very different styles, each illustrates a significant trend in the scientific representation of the Other during the last half of the 20th century. This article analyses the films with particular attention to Meldgaard's changing ways of engaging with the Inuit as objects and subjects, respectively. It also compares Meldgaard's films with his two books on Inuit art, and discusses his films in the context of contemporary methodological developments in archaeology and anthropology. It concludes by recommending that future archaeologists follow Meldgaard's example and engage in sharing knowledge, through audiovisual media, with people affected by archaeological excavations, instead of letting media professionals take over the representation of archaeological knowledge.
\end{abstract} * The National Museum of Denmark, Research and Exhibitions, Ethnographic Collections,
Frederiksholms Kanal 12, DK-1220 Copenhagen K, Denmark. Anne.Mette.Joergensen@ @atmus.dk 


\section{Introduction}

Danish archaeologist Jørgen Meldgaard (1927-2007) was renowned for his work in Greenland and in Igloolik (Canada) from the 1950s onwards. Together with curator Helge Larsen, he wrote the first continuous history of the three ancient populations of Greenland: the Saqqaq, Dorset, and Thule cultures (Larsen and Meldgaard 1958), based on excavations on the large midden at Sermermiut in Disko Bay in 1953 with archaeologist P.V. Glob and ethnologist George Nellemann. When in 1982 Jørgen Meldgaard and Helge Larsen excavated thousands of objects from all three cultures at the Qajaa site about $50 \mathrm{~km}$ from Sermermiut, Jørgen Meldgaard was further able to refine his theories (Meldgaard 1983).

Meldgaard was celebrated internationally for his archaeological achievements whilst another of his aspirations remained unknown, even to most of his colleagues. $\mathrm{He}$ was passionate about the use of film and photography on his field trips, not just for archaeology but also for anthropology and more artistic fields of interest. Meldgaard invested effort and money in his own film productions, but unfortunately along the way he tended to let his anthropological goals override these ambitious plans. He edited only a small part of the many hours of footage he had carefully shot and brought home to the National Museum in Copenhagen from Greenland and Canada, and as a result his films barely reached any audiences. Meldgaard largely reserved his visual and artistic tendencies for dissemination of Inuit art (Meldgaard 1959, 1960, 1982a) and for comprehensive photographic documentation. Today's archaeologists may still draw inspiration, however, from Meldgaard's initial efforts to include visual media as a means of sharing his archaeological research. They might want to experiment with and reflect on how visual media can serve the discipline through new opportunities for dialogue with people whose cultural heritage is affected by archaeological findings.

As an aspiring young student, Jørgen Meldgaard came to the National Museum of Denmark in 1945 and continued as a curator there from 1959 until retirement in 1997. After his death in 2007, his family gave the museum 15 boxes of his diaries, photographs, films, and other archival material. There, the SILA research centre was generously funded by the Rock Foundation to analyse and publicise this substantial archaeological and ethnographical material. In this article, I analyse Meldgaard's film footage, publications on Inuit art, and some of his photographs ${ }^{1}$ with particular attention to his ways of engaging with the Inuit. I will demonstrate how Meldgaard related to his informants in ways that may be described as dialogical, not just in a methodological sense but also on political issues of culture and heritage. From the very beginning, Meldgaard wanted to foster dialogue with informants in Greenland and Canada, and it is possible to identify similar dialogic elements in his visual works, and observe how they developed and impacted the course of his career.

\footnotetext{
1 Meldgaard's photographic collections consist of around 1,000 archaeological and anthropological photographs in various formats, and in black-and-white or colour. They might be comprehensively analysed in the future.
}

128/A.M. JØRGENSEN 
Jørgen Meldgaard's career illustrates two significant trends in archaeology in the last half-century. First, whereas archaeology and anthropology were inseparably interconnected when Meldgaard entered academia, from the 1960s onwards they consolidated as individual disciplines in European universities and became separated methodologically and epistemologically. This trend was very different from the one in North America, where the Boasian school favoured a four-field approach to anthropology, with one of the fields being archaeology. Another trend was that both archaeology and anthropology came to conform to certain conventions, described succinctly by the American visual anthropologist Edmund Carpenter as "the tradition that all experience was to be encompassed in a book. And a particular type of book and a particular type of format" (Carpenter in Bishop and Prins 2003). ${ }^{2}$

European scholars from both disciplines have responded differently to the increasing availability of visual media. Whereas archaeologists have almost entirely left filmmaking to professional production companies and television stations, a number of ethnographic filmmakers have over the decades produced professional or semiprofessional films. There has thus come into being a contested sub-discipline: visual anthropology. Starting with the early pioneers of ethnographic filmmaking, one of its pivotal points has been the relation between the object (the people filmed) and the subject (the filmmaker).

In the field, the camera became a source of interference, thus compelling much self-reflection among ethnographic filmmakers. As early as the mid-20th century, a handful of visionary visual anthropologists experimented with collaborative and dialogical approaches (Jørgensen 2002: 10-14). These anthropologists gradually increased in number and heralded a broader anthropological debate in the 1980s that would later be called the anthropological "crisis of representation" (Clifford and Marcus 1986; Marcus and Fischer 1999[1986]). Today, experimental work is growing rapidly. With digital media becoming increasingly accessible, and new distribution channels being created, we are seeing more productions of professional quality and many, many more of variable quality on free platforms such as YouTube. Indigenous television producers and film companies, such as Isuma Productions in Igloolik and 3900 Pictures and Tumit Productions in Greenland, have begun producing feature films and documentaries, thereby blurring the former boundaries between object and subject.

Archaeologists, too, may profit further from new technologies to communicate visually with different audiences. "Films and video offer 'a lively way into the past"" (Caveille n.d. in Van Dyke 2006: 371). Van Dyke (2006: 372) encourages archaeologists to take control of such communication. "When we uncritically adopt genre conventions, we may be unintentionally reifying and communicating ideas such as the exotic 'otherness' of the past, or the separation of archaeological labour and interpretation. Archaeologists should make sure to be critically engaged with the structure, as well as the content, of our documentaries." Because fieldwork is central to

2 A full transcript of the film by Bishop and Prins (2003) may be downloaded from a website containing numerous resources on Edmund Carpenter (Mediated Cultures n.d.). 
both disciplines, archaeologists and anthropologists share ethical concerns over engagement with informants and other people living in areas of fieldwork (Nicholas et al. 2011). Anthropologists' concerns for people portrayed in ethnographic film are mirrored by archaeologists' concerns for people affected by archaeological findings, not least Indigenous people "whose past is often the subject of archaeological study, and despite decades of objection, still have too little voice in conduct of research, share too few of its benefits, and consequently often do not support studies that could improve knowledge and appreciation for their cultural heritage" (Archaeology Channel n.d.). Skilful visual communication has to allow for and work with such intercultural sensitivities. Consequently, renewed interconnection between archaeology and anthropology may become relevant, at least in the sense of sharing experiences about engagements with the public through visual media.

\section{Images of Inuit life: Godthåbsfjorden 1952 and Igloolik 1954}

Since its early decades, the history of filmmaking has been intertwined with Arctic exploration and research. Expedition leaders and researchers were fascinated by the communicative potentials of the new medium, and brought movie cameras on many expeditions to the Arctic. Danish films were first made in Greenland as early as 1908 on the Denmark Expedition (Sperschneider 1998) but are apparently and unfortunately lost, as is the film documentation of Robert Peary's return from the North Pole. There still is, however, film footage of his rival Dr. Cook returning to Copenhagen in 1909 (ibid.: 59). More comprehensive Danish films were first made in 1914 in Nanortalik in southern Greenland by linguist and ethnographer William Thalbitzer (1914: 60), who documented among other things the use of umiaks, kayaks, and sod houses. Although preceded by The Romance of the Far Fur Country (Hudson's Bay Company 1920) from the same area, Nanook of the North, filmed in Northern Quebec in 1921 by the Canadian filmmaker/anthropologist Robert Flaherty, is probably the most widely known Arctic film of all time, often praised for its ethnographic accuracy and cinematographic beauty. ${ }^{3}$ In these early decades of filmmaking, Canadian, American, Danish, and French expeditions brought back an increasing number of films about Inuit life in remote areas (e.g., Dalsheim 1934; Hansen 1926; Macmillan 1926; Matter 19384; Rimmen 1934). In almost all of these films, the allegedly unchanging Inuit way of life is juxtaposed with the energetic European explorers, portrayed as heroes overcoming dangers, physical hardship and starvation, conquering unknown lands,

3 Nanook of the North (Flaherty 1922) became a milestone in the history of Arctic film. It was the first feature-length film recorded in the Arctic and was produced to appeal broadly to audiences of the still new medium of cinematography. Under the full title Nanook of the North - A Story of Life and Love in the Actual Arctic, it presented the Inuit way of life of Allakariallok, alias Nanook, to cinema screens all over North America and Europe, where it greatly influenced how the public imagined the Inuit. Flaherty's strategy of asking real people to act themselves - thereby imitating documentary while simultaneously drawing on the cinematographic advantages of the feature film-exemplied the trend of cinéma vérité in ethnographic filmmaking from mid-century onwards.

4 Les quatre du Groenland (Matter 1938) was filmed on a French expedition to East Greenland by, among others, explorer and ethnographer Paul-Émile Victor in 1935-1936.

\section{0/A.M. JØRGENSEN}


collecting new scientific results and, in the end, returning home to scenes of glorious welcome. ${ }^{5}$

These film conventions are echoed in Jørgen Meldgaard's 1952 film from the Godthåbsfjorden (today the Nuuk Fjord). Meldgaard was merely a student when he headed this research trip with young Danish researchers George Nellemann and Inge Kleivan and Canadian archaeologist Claude DesGoffe. Meldgaard had raised money from the Commission for Scientific Research in Greenland for the manifold aims of the expedition. One aim was to conduct topographical surveys so that the Danish Geodetic Institute could draw maps of prehistoric sites in the fjord area; another was to inspect known Norse and Inuit ruins; and a third was to continue ethnographic research already initiated by a colleague, C.L. Vebæk (Meldgaard 1952a, 1953). Young Greenlandic boatmen and carriers provided local knowledge about landscapes, structures, myths, and other aspects of life in the areas visited (ibid. 1952a, 1952b). Already, at this early stage in his career, Meldgaard was taking the initial steps towards his characteristic combination of methods, thus laying the groundwork for later strategies of comparison and analogy, and for a continual oscillation between new theories based on excavations and observations of people living in a particular area.

Meldgaard's first film does not reveal much about the expedition's scientific goals, and his diary only mentions the camera once when there are technical problems. The original intention may have been to document the young Meldgaard and his colleagues being introduced to Greenland in the tradition of his heroes, particularly Knud Rasmussen. The viewer is provided with a visually comforting experience that respects the conventions of traditional films about Arctic expeditions. The film opens with long takes of sailing into the beautiful mountainous landscape of the fjord aboard the Daniel Bruun. Young local men are seen from the rear, fishing from the boat. A man casts anchor. A smaller boat takes the expedition members ashore. In a long take, Daniel Bruun vanishes slowly towards the horizon while everybody is waving goodbye: the link to "civilisation" is cut. The expedition members, with heavy backpacks and rifles, set out in single file on their long walk. Short breaks leave time for the camera to pan over the young adventurers one by one, the Greenlandic guides included, as they kneel down to pluck blueberries or to wash their faces in a clear cold brook. The camera eye stays with the expedition members, providing a pleasant impression of taking part in the intimate relationship of the little group and sharing their experience of impressive landscapes, poetic flowers, gushing rivers, juicy berries, and bothersome mosquitoes. The grandeur of the scenery is breathtaking and thoroughly documented in stills of mountains, flowers, and icebergs, including as many as 16 pan shots of landscapes during the 37 minutes of the film. The desertedness is conspicuous; only now and then may a single boat or wooden structure be glimpsed on the horizon. The viewer is left with a feeling of being far away from civilisation, in the real Arctic outback.

5 The Wedding of Palo (Dalsheim 1934) is a notable exception to the rule. It is a fiction film, written by Knud Rasmussen, enacted by Greenlanders, and telling an authentic story about Inuit life and love in East Greenland. 
But the remoteness is an illusion. At that time the Godthåbsfjord already had boats of all sizes busily carrying goods and people to and from the colonial capital city of Godthåb (today Nuuk). The image of a rural and remote setting is further underlined by the exclusion of footage about Godthåb, from where the expedition set off. No room was left for images of a big and modern city.

Not until 10 minutes into the film does the camera show one of the destinations of the expedition, the archaeological site of Nipaatsoq, from which the group rapidly unearths a whole heap of animal bones. One minute later they find the scratched initials of archaeologist Eigil Knuth on a wall outside a cave. Five minutes later we get to meet local Greenlanders, as the expedition visits small villages, such as Kapisillit and Qoornoq. The film continues, mixing beautiful and scarcely populated landscapes with journeys into little known territories, remote villages, and archaeological sites, including the impressive, exceptionally preserved, and fully dressed mummies of a cave in Pisissarfik Mountain.

The fictional aura of the film is further reinforced when a visit to the village of Qoornoq concludes with the camera panning upward from a pile of bones, over a pair of red kamiks (boots), black and white sealskin shorts, a red anorak, and a colourful bead collar, and on to a young Greenlandic girl's face. The girl in her beautiful national gown curiously grabs pieces of bones and turns them over while we watch her from a frog's perspective and look up towards the blue sky. Was it Meldgaard's intention with this mise en scène to indicate that the young nation of Greenland will prosper if it builds on its rich prehistory? In any case, Meldgaard would dedicate his career to uncovering and interpreting this prehistory.

This was indeed the pretext when, two years later, Meldgaard again embarked on a film project while leading an archaeological expedition to Igloolik Island in the Canadian Eastern Arctic. The crew members included a young anthropologist and filmmaker, Richard Emerick, and were greatly assisted by Father Guy MaryRoussilière, who was familiar with the myths, customs, and traditions of the people in the area, and by local hunter and artist Pacôme Qulaut. The expedition surveyed large areas for structures and conducted extensive excavations at Pre-Dorset, Dorset, and Thule sites. According to Meldgaard's (1952b) diary, another ambitious aim was to record material for two films: an ethnographic one about the walrus-hunting Iglulingmiut people, and another one about the archaeological excavations. Meldgaard and Emerick ended up with only the ethnographic film about the Iglulingmiut hunters, The Eskimo (Emerick and Meldgaard 1954).

The film is mainly a portrayal of the Iglulingmiut men hunting seal, walrus, and a polar bear, skilfully slaughtering the animals, and bringing them home to the women and children to share and store within the domestic sphere. With its descriptive style, respectful tempo, and sense of detail, the film offers the viewer an informative and beautiful experience of life in this barren area "on the rim of existence"- probably a significant point of interest for the young filmmakers and researchers. The hunting and butchering skills of the young Iglulingmiut men certainly impress the viewer. 
Unlike the Godthåbsfjord film that Meldgaard made two years earlier, there is dialogue with the people filmed in Igloolik. Whereas Meldgaard (1952c) chose to film the Greenlanders in the Godthåbsfjorden at a distance and rarely looking straight into the camera, in 1954 the camera meets the eyes of the Iglulingmiut men and curiously gazes over their shoulders while they are hunting, slaughtering, or socialising with their families around the blubber lamps. The camera's gaze perfectly reflects Meldgaard's very different ways of relating to people on these two field trips. Unlike his Greenland expedition in 1952, in 1954 Meldgaard lived for the first time among the Inuit for several months, and he developed a confident and equal relationship with the Iglulingmiut (Figure 1). The children stare and the women steal glances at the white men and their camera, whereas the men, on closer terms with Meldgaard, look trustfully and grinningly straight into the camera. In this sense the camera never lies, since the nature of the relationship between a group of people and a team of foreign filmmakers is easily readable in the eyes of the people on the screen. This is so even though the film is a silent movie. ${ }^{6}$ Typically for ethnographic films of the mid-20th century, its universe is masculine. This male focus changed only slowly in the decades to come, as the number of female ethnographers and filmmakers increased. In general, the future would see a diversification of film conventions, not least stimulatingly as Inuit filmmakers entered the scene. One of these, Zacharias Kunuk (b. 1957) from Igloolik, would film his award-winning Atanarjuat (Kunuk 2001) there.

Few people went to see The Eskimo, perhaps because it was a silent movie. In 2001, shortly before he died, Richard Emerick, together with the Hudson Museum's Public Relations Department, re-edited it and added a new narrative and highly informative soundtrack. Renamed Iglulingmiut: Inuit Hunters in Transition (Emerick 2001), this film now is screened for the Hudson Museum public on a regular basis. Although the raw material of both versions is obviously the same, except for the addition of a few photographs, the new version is strikingly different because of Emerick's emphasis on the transitory features of Iglulingmiut ways of life. This emphasis appears in the title and is further substantiated by Emerick's narration, which highlights what was only observable for the particularly attentive viewer in the first version, e.g., a visit by the hunters to the trading post or the presence of foreign conveniences, such as an alarm clock in a family tent.

While Meldgaard probably did not shoot any footage for the Igloolik film, he eagerly used his photo camera on the same expedition and later ones to the Igloolik area. His ethnographic photographs reached large audiences, not least when some of the photos were published in a revised edition of the monograph The Eskimos by Kaj Birket-Smith in 1960. In publishing these photographs, the senior professor inscribed Meldgaard's name on the roll of honour of great Arctic explorers, the others including

6 Around the year 1960, the very first synchronous sound cameras became available. This technical landmark offered ethnographic and documentary filmmakers in cross-cultural settings the possibility of giving voice to the subjects of research. With the notable exception of several films by Jean Rouch (Rouch 1959, 1961; Rouch and Morin 1960), the new potential for more dialogue slowly took over in the following decades from the typically more authoritarian commentary of documentaries (Jørgensen 2002: 13; Loizos 1993: 16-29). 
Helge Larsen, Knud Rasmussen, Peter Freuchen, and William Thalbitzer. And with good reason: the photographs convey Meldgaard's sincere interest in the Iglulingmiut and their way of life. Presence is a key word to reading these photographs. Like Emerick with the movie camera, Meldgaard with the photo camera was not afraid of moving close to people, and viewers get the impression of being together with the Iglulingmiut in their boats, tents, and dogsleds, or just standing on the ice during long Arctic nights or days when the sun never rises or sets (Figure 2). The pioneering visual anthropologist and friend of Meldgaard, Edmund Carpenter, also used photographs by Meldgaard, albeit only images of museum artifacts, when he published his outstandingly poetic and evocative experience of living with the Aivilik Inuit of the Canadian Eastern Arctic, Eskimo Realities (Carpenter 1973).

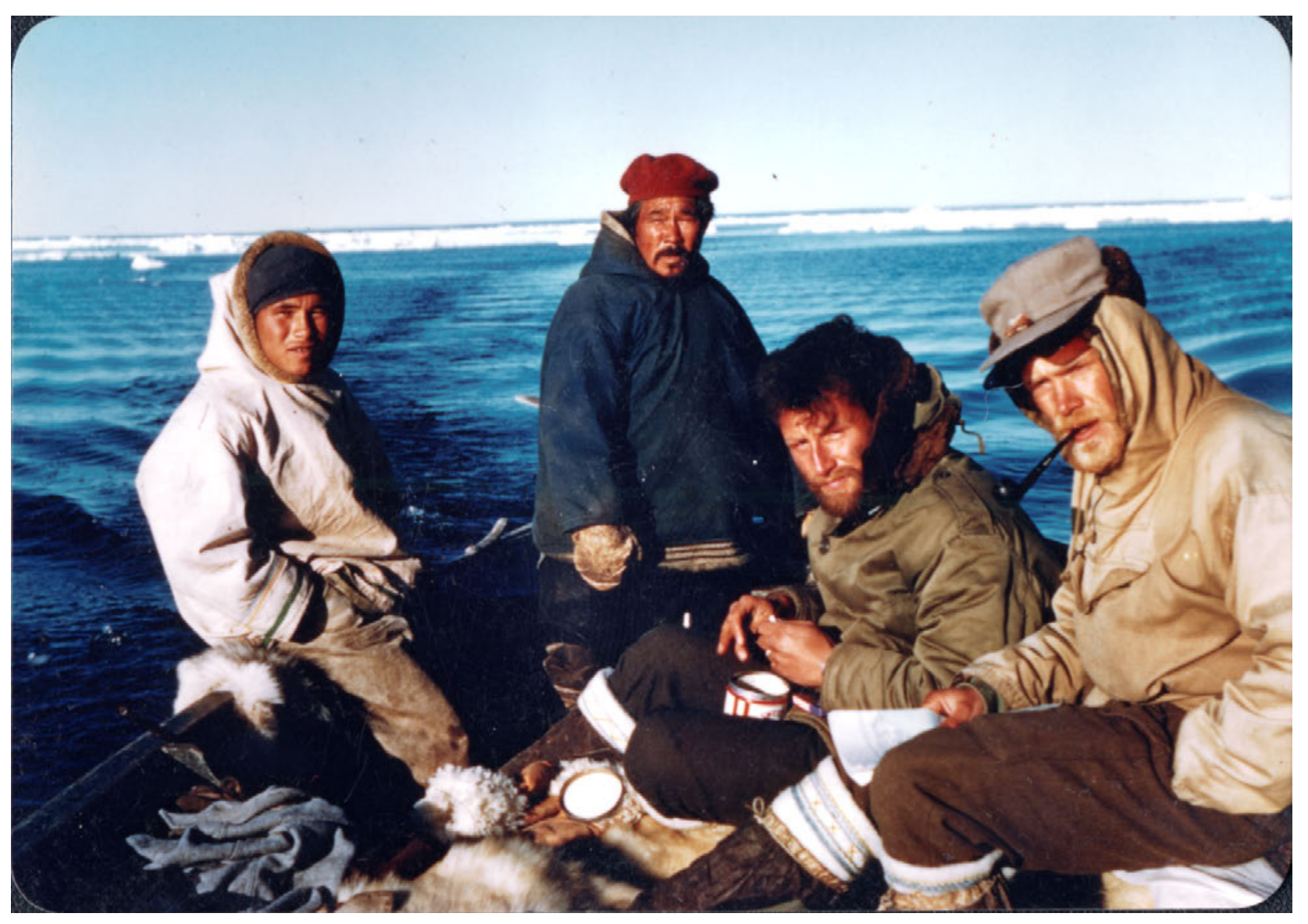

Figure 1. Left to right: Pacome Qulaut, Prime Itikuttuk, Father Louis Fournier, and Jørgen Meldgaard, Igloolik area, 1954. Photographer unknown. Source: Carpenter-Meldgaard Collection, National Museum of Denmark. 


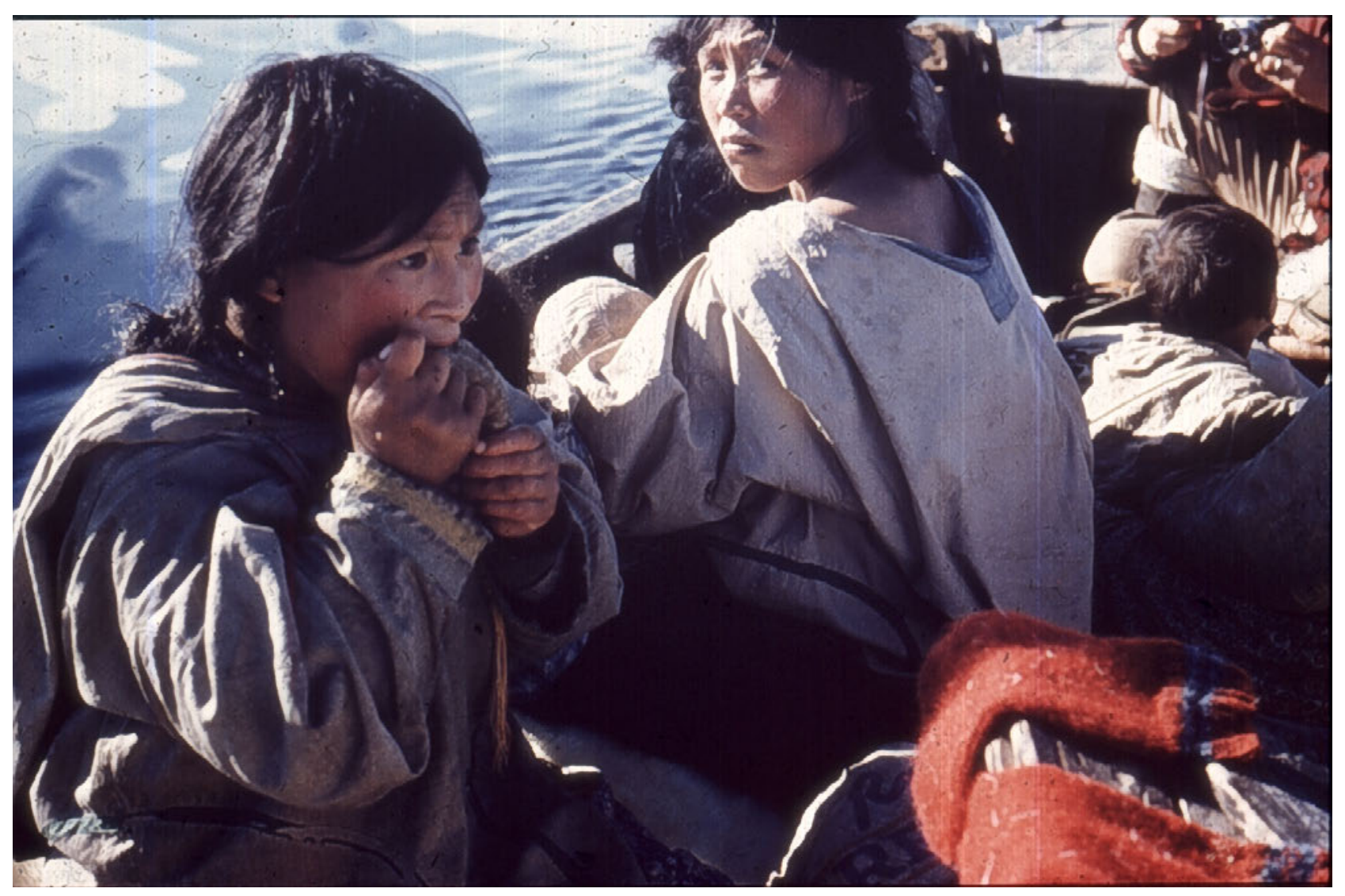

Figure 2. Left to right: Bertha Piujuq Tattatuapik and Elise Kuutikuttuk Qulaut, Igloolik area, 1954. Photographer: Jørgen Meldgaard. Source: Carpenter-Meldgaard Collection, National Museum of Denmark.

\section{Meldgaard and Inuit art}

Like many other archaeologists Jørgen Meldgaard was a capable illustrator who filled his diaries with sketch maps and drawings of excavated artifacts along with his writings. He was obsessed with maps and constantly on the lookout for significant visual structures when moving about in Arctic landscapes. He cherished the visual education of museum exhibits. He filmed, he photographed, and he performed on television. He chose these visual ways of communication because of his very strong concern for the audience and how they would respond. ${ }^{7}$ He perceived and interpreted the world in ways that must have been visually inspired to an exceptional degree. Archaeological evidence is by nature material and visible, and for Meldgaard visuality was taken as far as possible in his experiments with all of the available visual media and, in another regard, in his passion for Arctic art.

In 1959, Meldgaard published an introduction to Arctic art: Eskimo Skulptur (Meldgaard 1959). An English version, Eskimo Sculpture, came out the year after (Meldgaard 1960). Meldgaard passionately described and compared the physical

7 An example of Meldgaard's educational concerns is, ironically, his setting up of the first Scandinavian touch-and-feel exhibit for blind museum visitors (Bjarne Grønnow, pers. comm. 2012). 
appearance of artifacts and analysed how they were used and how they expressed social and cultural phenomena. If Meldgaard's interpretations in Eskimo Sculpture now and then appear authoritarian, being about art produced in the Arctic in all periods, his analysis of the outstanding Greenlandic artist Aron of Kangeq (Meldgaard 1982a) is a specific and personal appreciation of the artistic skills and vast local knowledge about life in southwest Greenland in the mid-19th century, as communicated in the aquarelles and wood engravings by Aron (1822-1869). Meldgaard analyses Aron as an artist and as a person, by looking through the archives and drawing on a rich correspondence with his mentors. Coming two decades after the first major volume on Aron (Knuth 1960), Meldgaard wrote this book in a climate marked by increasing national selfconsciousness in Greenland, following the introduction of Home Rule in 1979. He was aware that Aron's graphic illustrations provided a very rich source of knowledge about Inuit history, which in Greenland had until then been overshadowed by Danish history. The book was published simultaneously with the repatriation of locally produced works of art: 161 aquarelles by Aron from the National Museum of Denmark to the Greenland Landsmuseum, together with a collection of drawings by another skilled 19th-century Greenlandic artist, Jens Kreutzmann.

Meldgaard's enthusiasm for maps is mirrored by a section near the end of the book about early Greenlandic mapmakers. One outstanding map of a $20,000 \mathrm{~km}^{2}$ area in central Greenland, drawn freehand in 1863 by Jens Kreutzmann, must have caused Meldgaard trouble when laying out the book. In order to fit the format, the very detailed map had to be downscaled to such an extent that the text became unreadable. Determined not to give up, Meldgaard chose to include the diminished map and advised his readers that it was "[...] to be read with a magnifying glass" (Meldgaard 1982a: 101).

\section{Filming the groundbreaking excavations of Qajaa, 1982}

After the 1954 filming in the Igloolik area, Meldgaard for almost three decades abandoned the use of movie cameras and turned to other activities. The Igloolik film became his first and last ethnographic film, and Meldgaard's career in this sense reflects a general European trend to separate archaeology from anthropology. An exception was the Department of Ethnography of the National Museum in Copenhagen, which continued to employ-and still employs-both archaeological and anthropological curators.

Meldgaard's scholarly orientation in the 1960s and 1970s increasingly turned towards archaeology while, on a political level, he headed the preparations for a Greenlandic museum of cultural history that opened in 1968 . He was a leading force in pioneering the repatriation from 1982 to 2001 of around 35,000 ethnographic and archaeological museum artifacts to Greenland, starting with the above-mentioned aquarelles by Aron and Kreutzmann, which today constitute the backbone of the Greenland National Museum and Archives (Grønnow and Jensen 2007: 180). 
In this new climate of, if not equality, then mutual understanding, the ways of communicating in the field had shifted markedly from Meldgaard's first excavations. When he and his Danish colleagues in 1982 set out to excavate the Qajaa site, collaboration was the ideal and elements thereof were explicitly articulated when the camera was shooting. Meldgaard knew in advance that these excavations would uncover significant Palaeo-Eskimo material, as the team had located a significantly large permafrost-protected site. He therefore brought a Betamax video camera and a number of tapes, consulted a professional documentary filmmaker, and ambitiously filmed during the whole period of the excavation (Meldgaard 1982b).

For this excavation Meldgaard had again brought together a strong team, including his mentor, the aging curator and archaeologist Helge Larsen (Figure 3), zoologist Jeppe Møhl, two young Greenlanders, Regine Jørgensen and Hans Lange, and a group of enthusiastic local amateur archaeologists. In 30 days, they dug up hundreds of spectacular artifacts, many until then largely unknown in the Arctic, since the permafrost had protected the organic material. Well-defined layers without any artifacts bore witness to periods of time without human presence on the site, and they clearly separated three successive periods of settlement, namely the Saqqaq culture, the Dorset culture, and the Thule culture. Refined analysis now became possible, not least as a means to know more about contact between some of the three cultures.

Meldgaard enthusiastically filmed all the excavations. Now and then, he handed over the camera to Regine Jørgensen, and jumped into the frame to communicate with his imaginary audience. Meldgaard was an outstanding storyteller of Greenlandic myths and a knowledgeable expert on the geology, climate, and cultural history of the area, as well as on the modern scientific methods that now made excavation and analysis of the deep-frozen Qajaa material possible. With his knowledge of educational tools and entertaining tricks, he alternated between solo presentations and staged dialogues with the other archaeologists. He meticulously planned the sequences and filmed over and over again, often three or four times before he was satisfied. Hans Lange's local knowledge, Jeppe Møhl's zoological knowledge, and Helge Larsen's solid experiences with the Alaskan Arctic were brought into play in front of the camera.

Again and again Meldgaard's excavations in the Igloolik area served as a basis for comparison: "We have found a huge spearhead of whale bone 80 to $90 \mathrm{~cm}$ down, which means from 1700 to 1900 BC. It's the first time that we have seen such an example here in Greenland, but in every detail it resembles the ones we have found in Canada-for instance, the groove in it here"8 (Meldgaard 1982b). Meldgaard led the imaginary viewer through all the reasoning while the archaeologists discussed analogies between this and other excavations and agreed on explanations for the use and for the dating of each artifact. Over and over the words "for the first time in Greenland" are heard. As a viewer, one shares the excitement when the camera zooms in on microblades, knives, a complete needle, a needle case of walrus tusk, heads of arrows and harpoons, an amulet, and other items. Despite the repetitions and the

8 I have translated all quotations from Danish. 
staging of the scenes, the group skilfully acted out its reactions of surprise, for instance in the following dialogue:

Hans Lange: "This one comes from a seal."

Helge Larsen: "There's a hole in it. It looks like a tooth pendant. But you say it comes from a seal? I think Jeppe will decide."

Jeppe Møhl [walks into the frame]: "It is a tooth pendant [...] and the animal is a wolf $[\ldots]$ it's not a seal, and it's too big for a dog."

Jørgen Meldgaard [gets into the frame too, takes his pipe out of his mouth]: "Damn, what a surprise!" (Meldgaard 1982b)

Many scenes follow a prototype: the expert, often Helge Larsen or Jørgen Meldgaard himself, digs into the ground, cautiously uncovers an artifact, takes it into his hand and turns it over in front of the camera lens to interpret the artifact. This convention is often seen in archaeological films, and it serves to establish and substantiate the authority of a given expert. Looking over the archaeologist's shoulder while he works, one understands that this profession demands attentiveness, scrutiny, patience, a sense of detail and, at the same time, a sense of overall connections in time and space. Meldgaard and the other experts are portrayed as authorities; however-a sign of the times - they appear as authorities with human faces. Their humanness is underlined in substantial filming of life in the field. We see them fishing and preparing food, contemplating the picturesque landscapes, talking on the radio and, not least, joking and laughing. It was obviously crucial for Meldgaard that the Greenlanders and the Danes appear as equals in excavation work that served everybody's interest. In the film footage, he repeatedly mentions that this or that artifact must be handed over to the new museum in Nuuk after analysis.

In another obviously staged sequence, Helge Larsen sits on a museum box with "Nationalmuseet, Denmark's National Museum" printed on it, whereas Hans Lange is placed in front of him on a museum box with "Grønlands Landsmuseum" on it. Helge Larsen turns towards Hans Lange, pats his box, and says: "Well, Hans. It has been a good collaboration between the National Museum and..." Hans Lange: "Kalaallit Nunaata Katersugaasivia ('Grønlands Landsmuseum')" (Meldgaard 1982b). Larsen nods, with a satisfied air. The imaginary viewer has got the message: collaboration between Denmark and Greenland is essential.

Although Meldgaard put a very high priority on filming the excavations of the Qajaa site, the eight hours of carefully filmed footage were never turned into a television documentary as planned. Upon returning to Copenhagen, Meldgaard realised that the technical quality was poor, in particular the sound quality. He had to give up his ambitious project and left the material unedited.

One of the last shots from the Qajaa site shows Meldgaard inside his tent, talking to the camera, an ironic smile on his face: "Well, well, now this must be enough, all

\section{8/A.M. JØRGENSEN}


this video. This is a serious research assignment. However, we may try to prove that video is useful for much more than light entertainment" (Meldgaard 1982b). Meldgaard may have been uncertain about what status to assign to the moving images in comparison with his scientific projects. He had a good eye for the camera and obvious visual talents, but he seemingly wondered whether he could take the medium really seriously and therefore never fully allowed these personal skills to flourish.

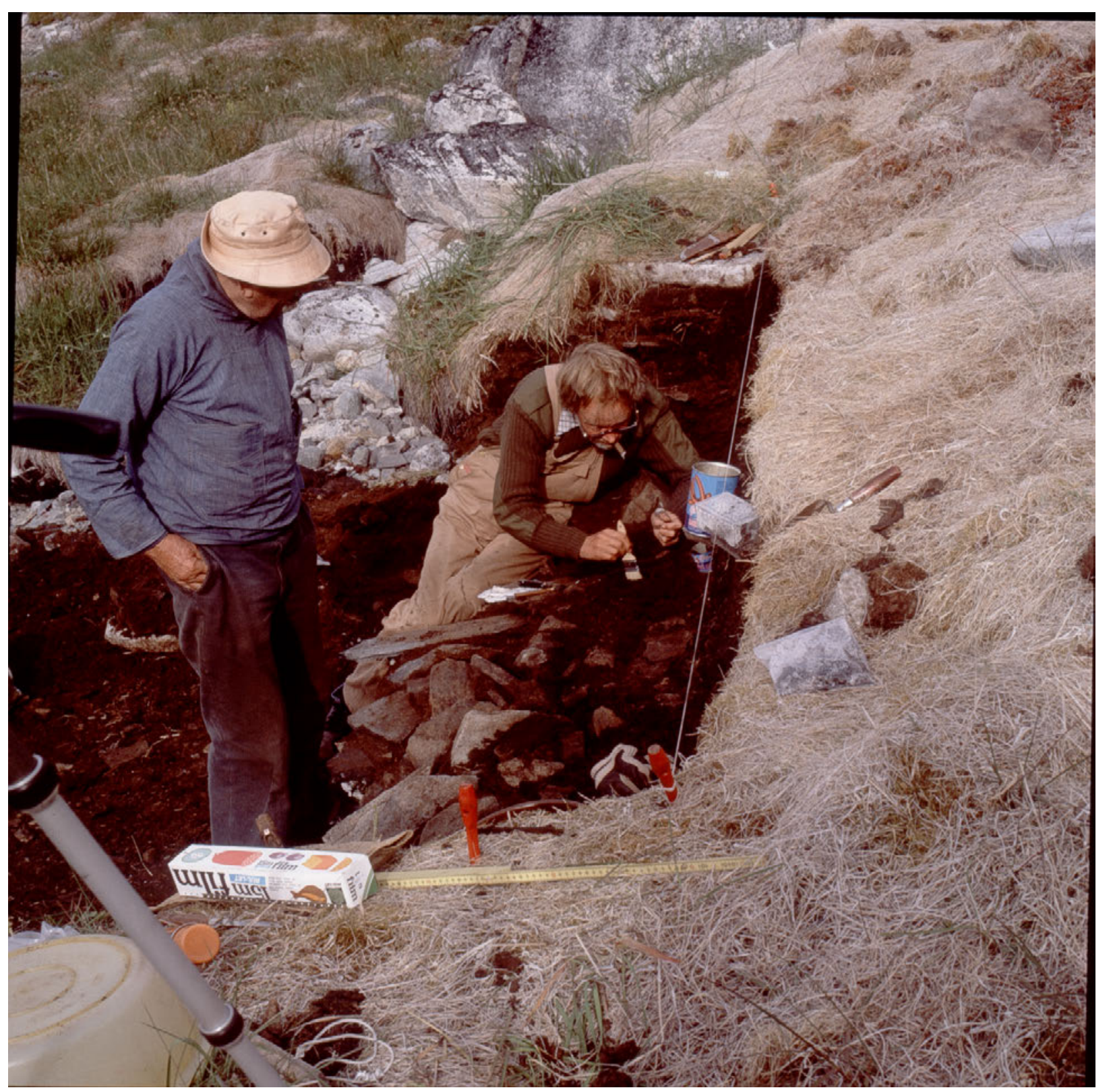

Figure 3. With Helge Larsen (left), Jørgen Meldgaard excavates one of the rich profiles of the Qajaa site in 1982. Photographer: Jeppe Møhl. Source: Carpenter-Meldgaard Collection, National Museum of Denmark.

\section{Conclusion}

During his career Meldgaard produced three major films. Filmed in very different styles, each film illustrates a significant trend in the way scientists have represented the 
Other during the last century. In Meldgaard's first film (1952c) the landscape around the Godthåbsfjorden, remote, fascinating, innocent, and (almost) untouched by the white man's hand, is the backdrop, a rich prehistoric heritage, against which the modern Greenlandic nation must be staged. The Greenlanders are represented as impersonal extras, whereas the viewer identifies with Meldgaard and the other expedition members, portrayed as young heroes and heroines in a style typical of the time. Two years later, the perspective changes markedly in the film The Eskimo (Emerick and Meldgaard 1954), which Meldgaard shot with anthropologist Richard Emerick. Here the camera dwells on men, women, and children as protagonists in a constant battle with nature-the barren Arctic. The Iglulingmiut are real people with faces and eyes looking straight into the camera, although portrayed not as individuals but as representatives of Inuit from all over the Arctic. Only about a decade later did the invention of portable synchronous sound equipment "give voice" to the protagonists of ethnographic films.

When in 1982 Meldgaard again embarked on a film project in the field, widely disseminated portrayals of Natives had become infamous in the wake of an anthropological crisis of representation and a political debate over the relationship between Greenland and its coloniser, Denmark. Probably influenced by anthropology's reflexive turn, the role of the Inuit, versus the role of the Danish researcher, had significantly changed scientifically, institutionally, and personally. In filming the excavations of the Qajaa site in Disko Bay, Meldgaard now focused on his Inuit colleagues as participants and partners with whom one could exchange knowledge, experiences, and artifacts. Equality is not a fitting term to describe the relationship, since the Danes undoubtedly played the role of scientific experts and educators, as opposed to the Greenlandic local experts, but all participating Greenlanders and Danes engaged in a common endeavour of uncovering the Arctic past. Since 1982, much has happened in the field of archaeology and in collaboration with so-called "descendant communities" all over the world (e.g., Nicholas et al. 2011). Under terms such as "Indigenous archaeology," "postcolonial archaeology," or "participatory archaeology," an increasing number of projects profit from including local participants, not least in field schools. Nicholas et al. (2011: 2) argue that "an even more mutually satisfying and relevant archaeology requires moving from participation to collaboration-the full and equal engagement in all aspects of the research process and the research products and benefits derived."

The Qajaa footage is a rare example of an archaeologist producing a film about his archaeological work. Meldgaard may inspire archaeologists at a time when camera and editing facilities are becoming increasingly affordable for semi-professionals and amateurs. Control over film production means control over the story being told, and it offers a politically engaged archaeologist the potential for dialogue with the societies affected by archaeological excavations. By documenting both the work of the archaeologists and the context of their life in the field during the excavations of the Qajaa site, Meldgaard communicated something on a general level about the nature of postcolonial relations between Greenlanders and Danes. Cultural history is political, and the archaeologist is complicit in defining and redefining the world for people living 
in areas of archaeological fieldwork. Engaging dialogically, yet asymmetrically, with his Greenlandic colleagues, Meldgaard revealed his complicity (Marcus 1998: 122; 2010) in creating this field situation. The time was not ripe for collaborative archaeology, but Meldgaard laid foundation stones for later postcolonial collaboration. It was not explicitly stated, but he implicitly represented the former colonial power, Denmark, in an attempt to correct past inequalities and share knowledge for a common good.

Fieldwork, both archaeological and anthropological, depends in great measure on vision and visual abstractions (Fabian 1983: 106-107; Marcus and Clifford 1986). Archaeologists use visual media extensively (including modern technologies like GPS and GIS) as documentation, educational illustrations, and data. However, when using audiovisual media to communicate knowledge to a broader audience, archaeologists tend to leave the job to professionals, except for a few notable exceptions, ${ }^{9}$ and the dominant conventions in such productions still give the archaeologist a highly authoritative voice. As recommended in a recent study guide: "We should pay more attention to just what it is that images say about us as archaeologists, our profession, and our concern for our audiences, not just what we think they say about the archaeological record" (Zimmerman 2003: 48).

Meldgaard was a forerunner of visual archaeology. Although analysis of his legacy has hitherto focused on his substantial contributions to Arctic prehistory, and on his instrumental and pioneering work in repatriating artifacts and building Greenland's museums, a third and important legacy may be his inspiring example to future generations as someone who could use images and sound to reach audiences and thereby dialogue with those people who are affected by archaeological excavations.

\section{Acknowledgments}

For the preparation and writing of this article I am indebted to my colleagues at the Carpenter-Meldgaard Endowment at the SILA Research Centre, National Museum of Denmark, which is funded by the Rock Foundation and headed by Professor Bjarne Grønnow. Senior Researcher Martin Appelt aroused my curiosity about Arctic archaeology, particularly through his encouragement and insight. English proofreading was done by Simon Coury, the translation of the abstract into French by Anne-Hélène Kerbiriou, and the identification of the people in Figures 1 and 2 by Thoretta Iyerak.

\section{References}

\section{ARCHAEOLOGY CHANNEL}

n.d. About us (online at: http://www.archaeologychannel.org/about.html).

9 E.g., Hamilakis et al. (2001) and http://humanitieslab.stanford.edu/Metamedia/463. 


\section{BIRKET-SMITH, Kaj}

1960 The Eskimos, revised edition, translated by W.E. Calvert, London, Methuen, New York, Humanities Press.

BISHOP, John and Harald E.L. PRINS

2003 Oh what a blow that phantom gave me - Edmund Carpenter, DVD, 30 min.

CARPENTER, Edmund

1973 Eskimo Realities, photographs by Eberhard Otto, Fritz Spiess, and Jørgen Meldgaard, New York, Holt, Rinehart and Winston.

\section{CAVEILLE, Sean}

n.d. Ephemera: Archaeology on Television, video produced and directed by Sean Caveille, Bristol, University of Bristol, Department of Archaeology and Anthropology.

\section{CLIFFORD, James and George MARCUS (eds)}

1986 Writing Culture. The Poetics and Politics of Ethnography, Berkeley, Los Angeles, London, University of California Press.

DALSHEIM, Friedrich

1934 The Wedding of Palo, film, 79 min, Copenhagen, Palladium.

EMERICK, Richard and Jørgen MELDGAARD

1954 The Eskimo, film, Philadelphia, The University of Pennsylvania, Museum of Archaeology and Anthropology.

EMERICK, Richard

2001 The Iglulingmiut - Hunters in Transition, film, 25 min, Orono, University of Maine, Hudson Museum.

FABIAN, Johannes

1983 Time and the Other. How Anthropology Makes its Object, New York, Columbia University Press.

FLAHERTY, Robert J.

1922 Nanook of the North - A Story of Life and Love in the Actual Arctic, film, 72 $\min$.

GRØNNOW, Bjarne and Einar Lund JENSEN

2008 Utimut: Repatriation and Collaboration between Denmark and Greenland, in Utimut. Past Heritage - Future Partnerships, Copenhagen, IWGIA/NKA: 180-191. 
HAMILAKIS, Yannis, Mark PLUCIENNIK and Sarah TARLOW

2001 Academic Performance, Artistic Presentations, Assemblage: The University of Sheffield Graduate Journal of Archaeology, 6 (online at: http://www.assemblage.group.shef.ac.uk/issue6/art_web.html).

HANSEN, Leo

1926 By dog sledge across Alaska, film, 30 min, Copenhagen, National Museum of Denmark.

\section{HUDSON'S BAY COMPANY}

1920 The Romance of the Far Fur Country, film, Hudson's Bay Company.

JØRGENSEN, Anne Mette

2002 Etnografiske Dialoger. Jean Rouchs bidrag til antropologisk epistemologi og reprasentation, M.A. thesis, University of Aarhus, Aarhus.

KNUTH, Eigil

1960 Aron of Kangeq 1822-1869. The sealhunter, who became father of Greenland's art of painting, Copenhagen, National Museum of Denmark.

KUNUK, Zacharias

2001 Atanarjuat: The Fast Runner, film, 172 min, Igloolik, Isuma Igloolik Productions.

LARSEN, Helge and Jørgen MELDGAARD

1958 Paleo-Eskimo Cultures in Disko Bugt, West Greenland, Meddelelser om Grønland, 161(2):1-75.

LOIZOS, Peter

1993 Innovation in Ethnographic Film: From Innocence to Self-consciousness, 1955-85, Glasgow, Manchester University Press.

MacMILLAN, Donald B.

1926 The Far North: A Donald MacMillan Lecture Film, film, 120 min, Bowdoin, Peary-MacMillan Arctic Museum.

MARCUS, George

1998 The Uses of Complicity and the Changing Mise-en-Scène of Anthropological Fieldwork, in G. Marcus, Ethnography through thick and thin, New Jersey, Princeton University Press: 105-131.

2010 Contemporary Fieldwork Aesthetics in Art and Anthropology: Experiments in Collaboration and Intervention, Visual Anthropology, 23(4): 263-277. 
MARCUS, George E. and James CLIFFORD (eds)

1986 Writing Culture: The Poetics and Politics of Ethnography, Berkeley, University of California Press.

MARCUS, George E. and Michael M.J. FISCHER

1999 [1986] Anthropology as Cultural Critique - An Experimental Moment in the Human Sciences, second edition, Chicago, The University of Chicago Press.

MATTER, Fred

1938 Les quatre du Groenland, film, 30 min, Paris, Film Images.

\section{MEDIATED CULTURES}

n.d. Virtual Snow (online at http://www.mediatedcultures.net/phantom/).

MELDGAARD, Jørgen

1952a Plan for arkæoologisk undersøgelsesrejse $i$ Vest-Grønland i sommeren 1952, til Kommissionen for Videnskabelige Undersøgelser i Grønland, Copenhagen, National Museum of Denmark.

1952b Diary from Greenland 1952, 33-88, I-II, Copenhagen, National Museum of Denmark.

1952c [Godthåbsfjorden], edited $16 \mathrm{~mm}$ film material without title, Copenhagen, National Museum of Denmark.

1953 Redegфrelse for Nationalmuseets arkcologiske Unders $\phi$ gelsesrejse $i$ VestGrønland 1952, til Kommissionen for Videnskabelige Undersøgelser i Grønland, Copenhagen, National Museum of Denmark.

1959 Eskimo skulptur, Oslo, Dreyers Forlag.

1960 Eskimo Sculpture, London, Methuen.

1982a Aron. En af de markvardigste Billedsamlinger $i$ Verden, Copenhagen, National Museum of Denmark.

1982b [Qajaa], partly edited Betamax video material without title, Copenhagen, National Museum of Denmark.

1983 Qajâ, en køkkenmødding i dybfrost: feltrapport fra arbejdsmarken i Grønland, in Nationalmuseets arbejdsmark 1983, Copenhagen, National Museum of Denmark: 83-96. 
NICHOLAS, George P., Amy ROBERTS, Dave SCHAEPE, Joe WATKINS, Lyn LEADER-ELLIOT and Susan ROWLEY

2011 A Consideration of Theory, Principles and Practice in Collaborative Archaeology, Archaeological Review from Cambridge, 26(2): 14-58.

RIMMEN, H.F.

1934 Syvende Thule ekspedition, 15 min, Copenhagen, Dansk Film Co.

ROUCH, Jean

1959 Moi, un noir, film, 80 min, Paris, Films de la Pléiade.

1961 La pyramide humaine, film, 90 min, Paris, Films de la Pléiade.

ROUCH, Jean and Edgar MORIN

1960 Chronique d'un été, film, 90 min, Neuilly, Argos Film.

SPERSCHNEIDER, Werner

1998 Der Fremde Blick - Eskimos im Film, Ph.D. dissertation, Aarhus, University of Aarhus.

THALBITZER, William

1914 [Grønland 1914], film, 14 min, Copenhagen, National Museum of Denmark.

VAN DYKE, Ruth

2006 Seeing the Past: Visual Media in Archaeology, American Anthropologist, 108(2): 370-384.

ZIMMERMAN, Larry J.

2003 Visual Archaeology, in L.J. Zimmerman and William Green (eds), Presenting the Past, Rowman, Altamira, Archaeologist's Toolkit, 7: 47-59. 